\section{Development and Evaluation of Methods to Identify Sea Oats Breeding Lines for Beaches with Shallow Dunes}

\author{
Pheonah Nabukalu ${ }^{1}$ and Carrie A. Knott ${ }^{1,2,3}$
}

ADDITIONAL INDEX WORDS. coastal erosion, coastal restoration, ornamental grass, saturation tolerance, Uniola paniculata

SUMMARY. Sea oats (Uniola paniculata) is an aesthetically pleasing native plant used for beach restoration along the northern Gulf of Mexico coast. Many beaches in this region have shallow, saturated dune profiles, which reduces sea oats survival. The objective of this study was to develop methods to identify saturation-tolerant sea oats breeding lines. Sea oats seedlings were evaluated for saturation tolerance in greenhouse, beach, and field environments from 2010 to 2012. In 2010, sea oats grown under eight treatments (seven greenhouse treatments and a natural beach site) were examined. In 2010, sea oats seedling survival 2 and 3 months after transplanting (MAT) was greatest for four greenhouse treatments (nonflooded control, $6 \mathrm{~cm}$ cyclic flood, $6 \mathrm{~cm}$ static flood, and $10 \mathrm{~cm}$ cyclic flood) and least at the beach environment (Holly Beach, LA). In 2011 and 2012, sea oats grown under six treatments (four greenhouse treatments, a natural beach site, and a saturated field site) were examined. In 2011 , sea oats seedling survival 3 MAT ranged from $0.3 \%$ to $\mathbf{9 8 \%}$. The nonflooded greenhouse control had the greatest survival, whereas plants grown on dry bench regularly watered with 35 parts per thousand (ppt) saline solution had the least survival. Sea oats constantly flooded with $14 \mathrm{~cm}$ of saline water in the greenhouse had the least survival 2 and 3 MAT, $70 \%$ and $41 \%$, respectively. Sea oats survival when flooded with $14 \mathrm{~cm}$ of fresh water 3 MAT correlated with a saturated beach environment, Holly Beach, LA, 6 MAT $(r=0.970$, $P=0.030)$ and a saturated field environment, Baton Rouge, 6 MAT $(r=0.994, P=$ $0.006)$. These findings suggest that survival of sea oats grown in a greenhouse in 14 $\mathrm{cm}$ fresh water for 3 months correlates to sea oats survival at saturated beaches after 6 months, in the absence of significant storm events. Identifying protocols for selection of saturation-tolerant sea oats lines is essential to increase the efficiency and effectiveness of northern Gulf of Mexico sea oats breeding programs.

S ea oats, an ecological and aesthetic perennial dune grass, is planted on beaches in the northern Gulf of Mexico coast to reduce coastal erosion and restore natural ecosystems. Sea oats tolerate numerous harsh conditions and spread vegetatively in beach environments with underground rhizomes (Hester and Mendelssohn, 1987; Lonard et al., 2011, 2012; Wagner, 1964), which are stimulated to grow by sand burial (Lane et al., 2008; Wagner, 1964).

This manuscript is approved for publication by the Director of Louisiana Agricultural Experiment Station as manuscript number 2013-306-9382.

Financial support for this research was provided by USDA-NIFA

The authors thank the Harrison County Sand Beach Authority for sites to conduct the research.

${ }^{1}$ School of Plant, Environmental, and Soil Sciences, Louisiana State University Agricultural Center, 104 M.B. Sturgis Hall, Baton Rouge, LA 70803

${ }^{2}$ Current address: Department of Plant and Soil Sciences, University of Kentucky Research and Education Center, P.O. Box 469, Princeton, KY 42445

${ }^{3}$ Corresponding author. E-mail: carrie.knott@uky. edu.
Declining stands of sea oats in the northern Gulf of Mexico coast may result from shallow dune profiles typical of this area because of shoreline erosion (Couvillion et al., 2011; Morton et al., 2004), overwash events (Hester and Mendelssohn, 1987), low sediment supply (Davis, 1994; Houser et al., 2008), persistent onshore winds (Davis, 1994), and narrow beach widths that do not allow significant sand accumulation (Claudino-Sales et al., 2008). When dunes are shallow, sea oats grow at or near the water-table, which can contribute to plant death (Hester and Mendelssohn 1987). Soil saturation has long been identified as a major abiotic stress that markedly affects plant growth and development. As water saturates the soil pores, gases are displaced, a reduction in gas diffusion occurs, and phytotoxic compounds accumulate as anaerobic conditions prevail (VanToai et al., 2001). To our knowledge, the only reported study that investigated sea oats saturation tolerance was by Hester and Mendelssohn (1989). They examined the growth responses of sea oats to three watering regimes and four controlled water-table depths. They observed that excessive water from either inundation or shallow watertable depth negatively affected sea oats growth and survival. This may explain the decline of sea oats populations in areas of the northern Gulf of Mexico coast, particularly in Louisiana, Texas, and certain portions of Florida.

Most beaches in Louisiana are saturated beaches because of very shallow dune profiles (Couvillion et al., 2011; Hester and Mendelssohn, 1989). Consequently, sea oats populations are limited within Louisiana. To prevent the extinction of sea oats within Louisiana and other high-risk coastal dunes in the northern Gulf of Mexico coast and to improve its potential as an ornamental grass, saturation-tolerant sea oats lines are needed. In this study, we examined initial strategies toward testing, identifying, and developing saturationtolerant sea oats breeding lines for use in beach restoration and landscape management projects throughout the northern Gulf of Mexico coast. The specific objective was to determine whether greenhouse protocols or field environments could identify saturation-tolerant sea oats breeding lines to be used in beach restoration and landscaping projects.

\section{Materials and methods}

Sea oats seeds were collected Aug. 2009 from beach trials near

\begin{tabular}{llll}
\hline $\begin{array}{l}\text { Units } \\
\text { To convert U.S. to SI, } \\
\text { multiply by }\end{array}$ & U.S. unit & SI unit & $\begin{array}{l}\text { To convert SI to U.S., } \\
\text { multiply by }\end{array}$ \\
\hline 29.5735 & $\mathrm{fl} \mathrm{oz}$ & $\mathrm{mL}$ & 0.0338 \\
0.3048 & $\mathrm{ft}$ & $\mathrm{m}$ & 3.2808 \\
2.54 & inch $(\mathrm{es})$ & $\mathrm{cm}$ & 0.3937 \\
1.6093 & $\mathrm{mile}(\mathrm{s})$ & $\mathrm{km}$ & 0.6214 \\
7.4892 & $\mathrm{oz} / \mathrm{gal}$ & $\mathrm{g} \cdot \mathrm{L}^{-1}$ & 0.1335 \\
1 & $\mathrm{ppt}$ & $\mathrm{g} \cdot \mathrm{L}^{-1}$ & 1 \\
$\left({ }^{\circ} \mathrm{F}-32\right) \div 1.8$ & ${ }^{\circ} \mathrm{F}$ & ${ }^{\circ} \mathrm{C}$ & $\left({ }^{\circ} \mathrm{C} \times 1.8\right)+32$
\end{tabular}


Holly Beach, LA (lat. $29.761^{\circ} \mathrm{N}$, long. $93.568^{\circ} \mathrm{W}$ ) and Long Beach, MS (lat. $30.332^{\circ} \mathrm{N}$, long. $89.185^{\circ} \mathrm{W}$ ) (Bertrand-Garcia et al., 2012). Sea oats seed was surface sterilized with $25 \%$ chlorine bleach for $15 \mathrm{~min}$ (Woodhouse et al., 1968) before placement onto germination paper moistened with distilled water (International Seed Testing Association, 2008). Sea oats seeds were then germinated in the dark at $18.3{ }^{\circ} \mathrm{C}$ for $17 \mathrm{~h}$ and $35^{\circ} \mathrm{C}$ for $7 \mathrm{~h}$ (Woodhouse et al., 1968). After 2 weeks of germination, sea oats seedlings were transplanted into 72 -square-celled growing trays (11-8599; Hummert International, Earth City, MO) filled with commercial growing medium (Jiffy Mix plus; Jiffy Products of America, Batavia, IL) and placed in controlled greenhouse conditions maintained at $25{ }^{\circ} \mathrm{C}$ with natural photoperiod in the fall. When seedlings were $\approx 10$ to $12 \mathrm{~cm}$ tall, they were removed from growing trays and individually transplanted into 4 -inch traditional square pots (12-1403, Hummert International) filled with pine bark compost and sand $(1: 1)$ and maintained in the greenhouse in Fall 2009. Seedlings under greenhouse conditions were hand watered every $3 \mathrm{~d}$ with $\approx 50 \mathrm{~mL}$ fresh water before the experiment.

In Mar. 2010, a greenhouse study with seven treatments was initiated which had three water depths $(6,10$, and $14 \mathrm{~cm})$, two flood regimes (static and cyclic), and a nonflooded control (Table 1). A total of 160 seedlings, which were $\approx 6$ months old, at least $12 \mathrm{~cm}$ tall, and individually planted in 4-inch square pots containing $1: 1$ pine bark compost and sand mixture, were placed into each treatment. Flooded treatments were accomplished by placing the pots in plastic-lined wood-framed tanks that were $2.1 \times 1.25 \times 0.4 \mathrm{~m}$. Water in the flooded treatments was mechanically circulated with submersible fountain pumps (model YH-202; Quanzhou Yuanhua Electronic Technology Co., Fujian, China). The static flood regime $(S)$ continuously flooded sea oats plants. Water in the $S$ treatments was drained every $28 \mathrm{~d}$ and immediately refilled. Sea oats plants in the cyclic flood regime $(\mathrm{C})$ were flooded for $14 \mathrm{~d}$ and then no water for 14 $\mathrm{d}$ for 3 months. Sea oats plants in the control treatment were grown on a dry greenhouse bench and watered every $3 \mathrm{~d}$ with $\approx 50 \mathrm{~mL}$ of fresh water. All sea oats plants were fertilized every $14 \mathrm{~d}$ with $11.98 \mathrm{~g} \cdot \mathrm{L}^{-1} 20 \mathrm{~N}-4.4 \mathrm{P}-$ 16.6K water-soluble fertilizer (Peter's Peat Lite 20-10-20; Scott's Sierra Horticultural Products Co., Marysville, $\mathrm{OH})$. The experiment was conducted for 3 months and data were collected every 28 d. Survival, plant height, number of leaves per plant, root length, and fresh weight were measured in Apr., May, and June 2010. Plants with any green color were considered alive, while those without were considered dead. Plant height was measured from the soil level to the tip of the leaves, and the number of green leaves was counted. Forty sea oats seedlings per treatment, 10 per replication, were randomly selected and measured for total fresh weight biomass and root length every $28 \mathrm{~d}$. Roots were carefully removed from soil, washed with tap water, and dried with paper towels. Total fresh weight biomass was measured by weighing seedlings, and root length was measured from the shoot base to root tips (Table 2).

In July 2010, a beach trial with 360 sea oats seedlings obtained as described above, which were $\approx 3$ months old and at least $12 \mathrm{~cm}$ tall, was established at an extremely saturated beach with shallow dunes [not exceeding $2 \mathrm{~m}$ above sea level (Hester and Mendelssohn, 1987)] at Holly Beach, LA. Survival was measured in Aug., Sept., and Oct. 2010.

In Dec. 2011, a second greenhouse study was initiated; four treatments, including two salinity levels $(0$ and 35 ppt) and two flood levels $(0$ and $14 \mathrm{~cm})$, were examined. A total of 720 sea oats seedlings obtained as described in the 2010 experiment, which were 4 months old and at least $12 \mathrm{~cm}$ tall, were included: 180 seedlings for each treatment (Table 3). Salinity levels were obtained using salt (Instant Ocean ${ }^{\circledR}$; Aquarium Systems, Mentor, $\mathrm{OH}$ ) according to manufacturers' directions. Flooded treatments were accomplished as described above. Seedlings in the 0 -cm flood treatment were watered every $3 \mathrm{~d}$ with $\approx 50 \mathrm{~mL}$ of either fresh or saline water as required to achieve the treatment. Water in the flooded treatments was drained and immediately replaced every $28 \mathrm{~d}$. Survival was measured as described above every $28 \mathrm{~d}$.

In 2012, a beach trial and a field trial were initiated. In May, 304 seedlings, which were $\approx 8$ months old and at least $30 \mathrm{~cm}$ tall, were transplanted to an extremely saturated beach with shallow dunes at Holly Beach, LA. In Aug., 304 seedlings, which were $\approx 10$ months old and at least $30 \mathrm{~cm}$ tall, were transplanted to saturated fields at the Louisiana State University Agricultural Center's Burden Museum and Gardens (Burden), Baton Rouge, LA. Survival was measured as described above every $28 \mathrm{~d}$.

Statistical analyses. Analyses of variance were conducted as repeated measures for sea oats percent survival, plant height, number of leaves per plant, and root length using

Table 1. Mean sea oats survival in a controlled greenhouse trial at Baton Rouge, LA, with seven treatments having three water depths $[6,10$, and $14 \mathrm{~cm}(2.4,3.9$, and 5.5 inches) ], two flood regimes (static and cyclic), a nonflooded control, and saturated beach trial at Holly Beach, LA in 2010.

\begin{tabular}{lccc}
\hline & \multicolumn{3}{c}{ Survival (\%) } \\
\cline { 2 - 4 } Treatment $^{\mathrm{z}}$ & 1 $^{\text {MAT }}{ }^{\mathrm{y}}$ & $\mathbf{2 ~ M A T}$ & 3 MAT \\
\hline Control & $100.0 \mathrm{a}^{\mathrm{x}}$ & $99.0 \mathrm{a}$ & $98.0 \mathrm{a}$ \\
$6 \mathrm{C}$ & $98.0 \mathrm{a}$ & $100 \mathrm{a}$ & $98.0 \mathrm{a}$ \\
$6 \mathrm{~S}$ & $98.0 \mathrm{a}$ & $96.0 \mathrm{ab}$ & $92.0 \mathrm{a}$ \\
10C & $98.0 \mathrm{a}$ & $95.0 \mathrm{ab}$ & $92.0 \mathrm{a}$ \\
10S & $83.0 \mathrm{~b}$ & $78.0 \mathrm{~cd}$ & $69.0 \mathrm{~b}$ \\
14C & $91.0 \mathrm{ab}$ & $88.0 \mathrm{bc}$ & $80.0 \mathrm{~b}$ \\
14S & $81.0 \mathrm{~b}$ & $70.0 \mathrm{~d}$ & $41.0 \mathrm{c}$ \\
Holly Beach & $47.0 \mathrm{c}$ & $46.0 \mathrm{e}$ & $25.0 \mathrm{~d}$ \\
F value & $50.67^{* * *}$ & $44.15^{* * *}$ & $83.34^{* * *}$ \\
\hline
\end{tabular}

${ }^{\mathrm{z}}$ Control indicates sea oats plants were grown on dry bench and watered every $3 \mathrm{~d} ; 6,10$, and 14 indicate water depths were 6,10 , and $14 \mathrm{~cm}$, respectively; C indicates cyclic flood where sea oats plants were cyclically flooded for $14 \mathrm{~d}$ followed by $14 \mathrm{~d}$ of dry conditions; $S$ indicates static flood where sea oats plants were continuously flooded. ${ }^{\mathrm{y}} \mathrm{MAT}=$ months after transplanting.

${ }^{x}$ Means within a column followed by different letters are statistically different according to the $t$ test on difference of least square means $(P=0.05)$.

$* * *$ indicates $P<0.001$. 
Table 2. Mean plant height, number of leaves per plant, total fresh weight, and root length for sea oats grown under greenhouse conditions at Baton Rouge, LA in 2010 for seven treatments: three water depths $(6,10$, and $14 \mathrm{~cm})$, two flood regimes (static and cyclic), and a nonflooded control.

\begin{tabular}{|c|c|c|c|}
\hline \multirow[b]{2}{*}{ Treatment $^{\mathrm{z}}$} & 1 MAT $^{y}$ & 2 MAT & 3 MAT \\
\hline & \multicolumn{3}{|c|}{ Plant ht $(\mathrm{cm})^{\mathrm{x}}$} \\
\hline Control & $18.1 \mathrm{~cd}^{\mathrm{w}}$ & $18.1 \mathrm{~cd}$ & $19.1 \mathrm{~d}$ \\
\hline $6 \mathrm{C}$ & $18.8 \mathrm{bc}$ & $22.8 \mathrm{ab}$ & $28.1 \mathrm{~b}$ \\
\hline $6 S$ & $20.0 \mathrm{~b}$ & $21.0 \mathrm{~b}$ & $24.3 \mathrm{c}$ \\
\hline $10 \mathrm{C}$ & $16.7 \mathrm{~d}$ & $21.5 \mathrm{~b}$ & $33.2 \mathrm{a}$ \\
\hline $10 S$ & $17.8 \mathrm{~cd}$ & $21.7 \mathrm{~b}$ & $33.7 \mathrm{a}$ \\
\hline $14 \mathrm{C}$ & $22.2 \mathrm{a}$ & $23.9 \mathrm{a}$ & $30.6 \mathrm{ab}$ \\
\hline $14 S$ & $19.9 \mathrm{~b}$ & $20.7 \mathrm{~b}$ & $31.0 \mathrm{ab}$ \\
\hline \multirow[t]{2}{*}{ F value } & $9.71 * * *$ & $6.52 * * *$ & $22.92 * * *$ \\
\hline & \multicolumn{3}{|c|}{ Leaves (no.) } \\
\hline Control & $2.5 \mathrm{a}$ & $2.3 \mathrm{~d}$ & $2.4 \mathrm{c}$ \\
\hline $6 \mathrm{C}$ & $2.3 \mathrm{ab}$ & $3.6 \mathrm{a}$ & $3.6 \mathrm{a}$ \\
\hline $6 S$ & $2.3 \mathrm{ab}$ & $3.0 \mathrm{c}$ & $2.8 \mathrm{~b}$ \\
\hline $10 \mathrm{C}$ & $2.3 \mathrm{ab}$ & $3.7 \mathrm{a}$ & $3.9 \mathrm{a}$ \\
\hline $10 S$ & $2.1 \mathrm{bc}$ & $3.0 \mathrm{c}$ & $2.9 \mathrm{~b}$ \\
\hline $14 \mathrm{C}$ & $2.1 \mathrm{c}$ & $3.3 \mathrm{~b}$ & $3.0 \mathrm{~b}$ \\
\hline $14 \mathrm{~S}$ & $1.7 \mathrm{~d}$ & $2.3 \mathrm{~d}$ & $3.1 \mathrm{~b}$ \\
\hline \multirow[t]{2}{*}{ F value } & $9.90 * * *$ & $36.87 * * *$ & $17.90 * * *$ \\
\hline & \multicolumn{3}{|c|}{ Total fresh wt $(g)^{x}$} \\
\hline Control & $0.37 \mathrm{abc}$ & $0.43 \mathrm{~d}$ & $0.53 \mathrm{c}$ \\
\hline $6 \mathrm{C}$ & $0.35 \mathrm{c}$ & $0.54 \mathrm{~cd}$ & $0.75 \mathrm{~b}$ \\
\hline $6 S$ & $0.44 \mathrm{a}$ & $0.71 \mathrm{a}$ & $0.66 \mathrm{bc}$ \\
\hline $10 \mathrm{C}$ & $0.35 \mathrm{bc}$ & $0.69 \mathrm{ab}$ & $0.82 \mathrm{ab}$ \\
\hline $10 \mathrm{~S}$ & $0.37 \mathrm{abc}$ & $0.57 \mathrm{bc}$ & $0.95 \mathrm{a}$ \\
\hline $14 \mathrm{C}$ & $0.44 \mathrm{a}$ & $0.72 \mathrm{a}$ & $0.97 \mathrm{a}$ \\
\hline $14 S$ & $0.33 \mathrm{c}$ & $0.52 \mathrm{~cd}$ & $0.88 \mathrm{ab}$ \\
\hline \multirow[t]{2}{*}{ F value } & $2.14^{*}$ & $4.94 * * *$ & $6.07 * * *$ \\
\hline & \multicolumn{3}{|c|}{ Root length $(\mathrm{cm})$} \\
\hline Control & $24.4 \mathrm{a}$ & $30.3 \mathrm{a}$ & $33.0 \mathrm{a}$ \\
\hline $6 \mathrm{C}$ & $19.9 \mathrm{bc}$ & $18.6 \mathrm{~b}$ & $17.6 \mathrm{c}$ \\
\hline $6 S$ & $16.2 \mathrm{c}$ & $21.3 \mathrm{~b}$ & $18.4 \mathrm{c}$ \\
\hline $10 \mathrm{C}$ & $19.6 \mathrm{bc}$ & $19.7 \mathrm{~b}$ & $17.4 \mathrm{c}$ \\
\hline $10 \mathrm{~S}$ & $17.6 \mathrm{c}$ & $19.3 \mathrm{~b}$ & $19.9 \mathrm{bc}$ \\
\hline $14 \mathrm{C}$ & $23.5 \mathrm{ab}$ & $20.4 \mathrm{~b}$ & $23.5 \mathrm{~b}$ \\
\hline $14 S$ & $19.6 \mathrm{bc}$ & $21.9 \mathrm{~b}$ & $21.7 \mathrm{bc}$ \\
\hline$\underline{F}$ value & 3.72 ** & 3.01 ** & $16.29 * * *$ \\
\hline
\end{tabular}

${ }^{2}$ Control indicates sea oats plants were grown on dry bench and watered every $3 \mathrm{~d} ; 6,10$, and 14 indicate water depths were 6,10 , and $14 \mathrm{~cm}$, respectively; $C$ indicates cyclic flood where sea oats plants were cyclically flooded for $14 \mathrm{~d}$ followed by $14 \mathrm{~d}$ of dry conditions; $\mathrm{S}$ indicates static flood where sea oats plants were continuously flooded. ${ }^{\mathrm{y}} \mathrm{MAT}=$ months after transplanting.

${ }^{\mathrm{x}} \mathrm{l} \mathrm{cm}=0.3937$ inch, $\mathrm{l} \mathrm{g}=0.0353 \mathrm{oz}$.

wMeans within a column followed by different letters are statistically different according to the $t$ test on difference of least square means $(P=0.05)$.

$*, * *, * *$ indicate $P<0.05,0.01$, and 0.001 , respectively.

PROC MIXED in SAS ${ }^{\circledR}$ (version 9.1.3; SAS Institute, Cary, NC). Percent survival was arcsine square root transformed. Nontransformed data are reported; data interpretations were based on transformed data. Analyses of variances were conducted for fresh weight biomass using PROC MIXED in SAS ${ }^{\circledR}$ (version 9.1.3). In 2010, the greenhouse environment was a randomized complete block design with four replications; each replication had 40 plants. In 2010 , the beach environment was a completely randomized design with 360 total seedlings; four replications of 80 plants. The 2011 greenhouse experiment was a randomized complete block factorial design (two salinity and two flood levels) with 720 seedlings; four replications of 45 seedlings. In 2012 , the beach and field trials were completely randomized design with 304 total seedlings; four replications of 76 plants. Least squares means were used for means separation at the $P<0.05$ level with pdmix (Saxton, 1998). Pearson's correlation coefficients were calculated using PROC CORR in SAS ${ }^{\circledR}$ (version 9.1.3) for percent survival 2011 greenhouse treatments and 2012 beach and field trials.

\section{Results and discussion}

In 2010, greenhouse and beach trials showed significant $(P<0.05)$ treatment by time interactions for survival, plant height, leaf numbers, fresh weight, and root length; therefore, data were analyzed separately for each month. One MAT, survival of sea oats seedlings ranged from $47 \%$ to $100 \%$. The nonflooded greenhouse control (watered every $3 \mathrm{~d}$ ) had the greatest survival, $100 \%$, while the beach site, Holly Beach, had the least survival, $47 \%$ (Table 1). In the greenhouse environment, sea oats seedling survival was least for seedlings constantly flooded at $10 \mathrm{~cm}(10 S)$ and $14 \mathrm{~cm}$ (14S), $83 \%$ and $81 \%$, respectively (Table 1). Sea oats seedling survival 2 and 3 MAT was greatest for the control, cyclic flood at $6 \mathrm{~cm}(6 \mathrm{C})$, static flood at $6 \mathrm{~cm}(6 \mathrm{~S})$, and cyclic flood at $10 \mathrm{~cm}$ (10C) and least at Holly Beach (Table 1). The least survival among greenhouse treatments was observed in $14 \mathrm{~S}$, with $70 \%$ and $41 \%$ at 2 and 3 MAT, respectively. We also found that survival in saturated beach conditions at Holly Beach, LA, was always lesser when compared with greenhouse treatments.

The combination of multiple extreme environmental conditions likely resulted in high $(P<0.05)$ sea oats mortality at Holly Beach in 2010. About 2 weeks before sea oats plantings at Holly Beach, Hurricane Alex made landfall near Soto la Marina, Tamaulipas, Mexico (lat. $23.769^{\circ} \mathrm{N}$, long. $\left.98.205^{\circ} \mathrm{W}\right) ; \approx 800 \mathrm{~km}$ southwest of Holly Beach. Hurricane Alex generated storm surge that flooded Holly Beach. In addition, $22 \mathrm{~cm}$ rainfall occurred within the first $28 \mathrm{~d}$ after transplant, which is $\approx 9 \mathrm{~cm}$ above the mean. Finally, the mean low air temperature at Holly Beach 1 month after transplant was $24.7^{\circ} \mathrm{C}$, while the mean low temperature in the greenhouse trial was $20^{\circ} \mathrm{C}$. We have observed that daily low temperatures exceeding $20{ }^{\circ} \mathrm{C}$ reduce vegetative 
Table 3. Mean sea oats survival of plants evaluated in 2011 in controlled greenhouse (Baton Rouge, LA) with four treatments: two salinity levels [0 and 35 parts per thousand (ppt)] and two flood levels [0 and $14 \mathrm{~cm}(5.5$ inches) $]$, and in 2012 in saturated beach (Holly Beach, LA) and field (Baton Rouge, LA) conditions.

\begin{tabular}{lccr}
\hline & 1 MAT $^{\mathrm{y}}$ & 2 MAT & 3 MAT \\
\cline { 2 - 4 } Treatment $^{\mathrm{z}}$ & & Survival (\%) & \\
\hline 14Fr & $59.0 \mathrm{c}^{\mathrm{x}}$ & $28.3 \mathrm{~d}$ & $14.5 \mathrm{~d}$ \\
BSal & $81.9 \mathrm{~b}$ & $7.8 \mathrm{e}$ & $0.3 \mathrm{e}$ \\
14Sal & $94.9 \mathrm{a}$ & $73.0 \mathrm{~b}$ & $40.5 \mathrm{c}$ \\
GH control & $100.0 \mathrm{a}$ & $97.7 \mathrm{a}$ & $98.0 \mathrm{a}$ \\
Burden & $78.5 \mathrm{~b}$ & $56.7 \mathrm{c}$ & $45.8 \mathrm{c}$ \\
Holly Beach & $96.1 \mathrm{a}$ & $93.8 \mathrm{a}$ & $76.0 \mathrm{~b}$ \\
F value & $52.31^{* * *}$ & $219.75^{\star * *}$ & $190.99^{\star * *}$ \\
\hline
\end{tabular}

${ }^{\mathrm{z}} \mathrm{GH}$ control = sea oats plants were grown on dry bench and watered every $3 \mathrm{~d} ; 14 \mathrm{Fr}=$ sea oats plants were grown flooded to a depth of $14 \mathrm{~cm}$ with fresh water; BSal = sea oats plants were grown on dry bench and water every 3 $\mathrm{d}$ with $35 \mathrm{ppt}$ saline solution; $14 \mathrm{Sal}=$ sea oats plants were grown flooded with $35 \mathrm{ppt}$ saline solution at a flood depth of $14 \mathrm{~cm} ; \mathrm{l} \mathrm{ppt}=1 \mathrm{~g} \cdot \mathrm{L}^{-1}$

${ }^{y}$ MAT $=$ months after transplanting.

${ }^{x}$ Means within a column followed by different letters are statistically different according to the $t$ test on difference of least square means $(P=0.05)$.

$* * *$ indicates $P<0.001$.

growth of sea oats (C.A. Knott, unpublished data). Other investigators have reported that as daily temperatures increase, the vegetative growth of some plants species decreases after transplanting (Mohammed and Tarpley, 2011). It is possible that these combined environmental factors resulted in extreme plant stress and ultimately much greater mortality than in the greenhouse environment.

Plant height, leaf numbers, total fresh weight and root length were also measured in the 2010 greenhouse trial to better understand the response of sea oats to saturated growing conditions. We were unable to measure these traits for sea oats at Holly Beach because of the extremely time consuming and laborious nature of the measurements. In the greenhouse, plant height varied among treatments. At 1 MAT, plant height ranged from 16.66 to $22.18 \mathrm{~cm}(\mathrm{Ta}-$ ble 2). Plants grown in $14 \mathrm{C}$ had the tallest plants, while plants grown in 10C had the shortest plants (Table 2). At 2 MAT, plants under $14 \mathrm{C}$ had the tallest plants, whereas the control had the shortest plants (Table 2). At 3 MAT, plants grown in $10 \mathrm{C}$ and $10 \mathrm{~S}$ had the tallest plants and the control had the shortest plants (Table 2). It appears that sea oats seedlings respond to saturation stress by increasing in plant height. Similar findings (Banga et al., 1995; Sman et al., 1991; Striker et al., 2005; Vartapetian and Jackson, 1997; Voesenek et al., 2004) have been reported in several plant species.
Increased plant height is thought to be a survival mechanism to increase oxygen uptake by restoring contact of shoots with the atmosphere for increased access to aerated and illuminated zones above or close to the water surface (Armstrong, 1979; Laan and Blom, 1990; Laan et al., 1990).

We also found that the number of leaves differed significantly among experimental treatments. At 1 MAT, the control had the most leaves per plant and $14 \mathrm{~S}$ had the least (Table 2). At $2 \mathrm{MAT}, 6 \mathrm{~S}$ and $10 \mathrm{C}$ had the most leaves per plant, while the control and 14S had the least (Table 2). At 3 MAT, 6C and 10C had the most leaves and the control had the least (Table 2). When grown in saturated conditions, seedlings produced more leaves than plants grown in the nonsaturated control treatment; a similar observation was made by Grimoldi et al. (1999). Increased leaf numbers, another survival mechanism, increases the surface area making contact with oxygen, light, and carbon dioxide (Grimoldi et al., 1999).

Total fresh weight biomass and root length were also measured for sea oats seedlings grown in a greenhouse in 2010. At 1 MAT, biomass was greatest for seedlings grown at $6 \mathrm{~S}$ and $14 \mathrm{C}$ and least for $6 \mathrm{C}$ and $14 \mathrm{~S}$ (Table 2). At 2 MAT, sea oats plants under 6S and 14C still had the most biomass, while the control had the least (Table 2). At 3 MAT, $10 S$ and $14 \mathrm{C}$ had the greatest biomass, while the control had the least. Root length also varied significantly among different treatments. Sea oats seedlings grown under normal conditions (control treatment) had the longest roots 1,2 , and 3 MAT (Table 2 ). One MAT, 6S and IOS had the shortest roots; $2 \mathrm{MAT}$, all the flooded sea oats had short roots; and 3 MAT, 6C, 6S, and $10 \mathrm{C}$ had the shortest roots (Table $2)$. From this study, it appears that saturated conditions reduce normal root development in sea oats. This is a particularly important finding because the main mode of sea oats reproduction in the northern Gulf of Mexico coast is asexually from rhizome development and spread. The rapid decline of sea oats populations in areas of the northern Gulf of Mexico coast, especially Louisiana, may be due to reduced rhizome growth and therefore asexual reproduction and spread. It is also important to note that we observed sea oats plants grown in saturated conditions developed more adventitious roots at the soil level (data not shown). This could be another survival mechanism to replace roots that had been killed by anoxia (Vartapetian and Jackson, 1997). These roots usually emerge from the crown into surface layers to enhance oxygen transport (Visser et al., 1996) and reduce saturation injury.

In 2011, a second greenhouse trial was initiated to determine if greenhouse conditions could be used to predict saturated beach or field conditions. We examined four treatments: two salinity levels ( 0 and $35 \mathrm{ppt})$ and two flood levels $(0$ and $14 \mathrm{~cm})$. Saline treatments were added to simulate beach conditions after extreme episodic storm event accompanied with salt water intrusion. We chose $14-\mathrm{cm}$ constant flooding because this treatment provided the greatest mortality, tallest plants, and most plant biomass in the 2010 greenhouse trial. We established a beach trial at Holly Beach in 2012 to serve as the target environment for saturated beach conditions. We also included a field trial in a nonsaline saturated agronomic field at Louisiana State University Agricultural Center's Burden Museum and Gardens (Burden), Baton Rouge, LA, in 2012 to determine if a field environment rather than a greenhouse environment was necessary to predict performance of sea oats at saturated beach environments. 
Sea oats seedling survival in 2011 greenhouse and 2012 beach and field trials ranged from $59 \%$ to $100 \%$ l MAT. Survival was greatest when sea oats plants were grown in a greenhouse on a dry bench and watered regularly every $3 \mathrm{~d}$ ( $\mathrm{GH}$ control), flooded to $14 \mathrm{~cm}$ with 35 ppt saline solution (14Sal) and at Holly Beach (Table 3). Sea oats survival was least when sea oats seedlings were grown flooded to $14 \mathrm{~cm}$ with fresh water [14Fr (Table 3)], which was similar to what we observed in 2010 trial (Table 1). At 2 MAT, sea oats survival ranged from $7.8 \%$ to $97.7 \%$; the $\mathrm{GH}$ control and Holly Beach had the greatest survival while plants grown on dry bench regularly watered with $35 \mathrm{ppt}$ saline solution (BSal) had the least survival (Table 3 ). At 3 MAT, sea oats seedling survival ranged from $0.3 \%$ to 98\%; the GH control had the greatest survival, while plants under BSal had the least survival (Table 3 ). This indicates that in nonsaturated conditions, sea oats are very sensitive to saline conditions. Others have documented that although sea oats tolerate salt spray (Boyce, 1954; Valk, 1977), they are not salt-tolerant plants (Fine, 2000). It is also very interesting to note that survival of sea oats plants in 14Sal was consistently greater than survival of sea oats plants grown in $14 \mathrm{Fr}$ though we had expected the reverse to be true. Other investigators have reported that sea oats grow larger and are more vigorous when salt spray is present on leaves or when washed into root zones (Boyce, 1954; Valk, 1977). We anticipate that salt in the root zones could have provided essential micronutrients resulting in significant vegetative growth, more than in $14 \mathrm{Fr}$ with no salt additions. Unfortunately, we did not measure the amount of salt that had accumulated in the soil. More work is still needed to determine why survival of sea oats plants in 14Sal was consistently greater than survival of sea oats plants grown in 14Fr.

A significant difference in sea oats survival was found between Holly Beach in 2010 and 2012. In 2012, Holly Beach was unaffected by any major storm event before or within the first $28 \mathrm{~d}$ after transplant. We also measured plant survival 6 MAT for Holly Beach and Burden (data not shown). Survival was greater at Holly Beach, $74 \%$, than at Burden, $40 \%$. This is likely due to several confounding conditions. First, the water-holding capacity of the soils at Burden is much greater; Burden soil type was Oliver silt loam (fine-silty, mixed thermic, typic Fragiudalf), while Holly Beach was a sand and fine sediment (silt and clay) beach. Second, because of the effects of Hurricane Isaac in 2012, there was $31 \mathrm{~cm}$ rainfall within the first $28 \mathrm{~d}$ after transplant at Burden. Finally, temperatures were high with the mean low temperatures at Burden exceeding $22{ }^{\circ} \mathrm{C}$ the first $28 \mathrm{~d}$ after transplant.

Pearson's correlation coefficients $(r)$ were used to determine whether sea oats survival in greenhouse treatments could predict survival in saturated beach or field environments. Sea oats survival 3 MAT when grown in greenhouse with constant flooding at $14 \mathrm{~cm}$ with fresh water was significantly correlated with survival of sea oats 6 MAT at Holly Beach $(r=0.970$, $P=0.030)$ and Burden $(r=0.994, P=$ 0.006). We also used Pearson's correlation coefficients to determine whether field environment rather than greenhouse environment was necessary to predict survival of sea oats in saturated beach environments. No significant correlations were found between survival in field environments at Burden and saturated beach environments at Holly Beach (data not shown). The ability to predict sea oats survival in greenhouse conditions has significant implications for a saturation-tolerance breeding program. Selection of saturation-tolerant sea oats breeding lines after only 7 months (4-month-old plants and 3month assay) instead of 14 months (8-month-old plants and 6-month assay) would reduce the time to select sea oats saturation-tolerant lines, thus increasing the efficiency of the breeding program. Evaluation and development of sea oats breeding lines and varieties requires travel to beach sites, which is both time consuming and costly. If sea oats selection could be performed in an environment in close proximity to the breeders, the efficiency of the sea oats breeding program would be greatly improved leading to faster development of varieties and more efficient use of resources. It is noteworthy that the selected greenhouse treatment appears to be a good predictor of sea oats survival under saturated beach conditions in the absence of storm surge. However, after a significant storm event that produces storm surge, such as occurred at Holly Beach in 2010, significant correlations between greenhouse treatments and beach environments were not found.

\section{Conclusion}

From these preliminary results, we have identified a greenhouse protocol that can predict sea oats survival in half the time of saturated beach conditions. Sea oats screening can be completed in a greenhouse with constant flooding at $14 \mathrm{~cm}$ with fresh water for 3 months to predict survival at saturated beaches after 6 months, in the absence of significant storm events. Additional work would be needed to identify greenhouse conditions if selection for storm surge tolerance is desired. Development and identification of protocols for selection of saturation-tolerant sea oats breeding lines would increase both the efficiency and effectiveness of the sea oats breeding program, leading to faster development of varieties and more efficient use of resources.

\section{Literature cited}

Armstrong, W. 1979. Aeration in higher plants. Adv. Bot. Res. 7:236-332.

Banga, M., C.W.P.M. Blom, and L.A.C.J. Voesenek. 1995. Flood-induced leaf elongation in Rumex species: effects of water depth and water movements. New Phytol. 131:191-198.

Bertrand-Garcia, S.E., C.A. Knott, N. Baisakh, P.K. Subudhi, S.A. Harrison, M.D. Materne, and H. Utomo. 2012. Selection of genetically diverse sea oats lines with improved performance for coastal restoration in the northern Gulf of Mexico. Euphytica 185:103-117.

Boyce, S.G. 1954. The salt spray community. Ecol. Monogr. 24:29-67.

Claudino-Sales, V., P. Wang, and M.H. Horwitz. 2008. Factors controlling the survival of coastal dunes during multiple hurricane impacts in 2004 and 2005: Santa Rosa barrier island, Florida. Geomorphology 95:295-315.

Couvillion, B.R., J.A. Barras, G.D. Steyer, W. Sleavin, M. Fischer, H. Beck, N. Trahan, B. Griffin, and D. Heckman. 2011. Land area change in coastal Louisiana from 1932 
to 2010. U.S. Geological survey scientific investigation map 3164, scale 1:265,000. 18 July 2014. <http://pubs.usgs.gov/ $\operatorname{sim} / 3164>$.

Davis, R.A., Jr. 1994. Barriers of the Florida Gulf Penisula, p. 167-205. In: R.A. Davis, Jr. (ed.). Geology of Holocene barrier island systems. SpringerVerlag, Berlin, Germany.

Fine, G. 2000. Sea oats plant guide. 18 July 2014. <http://www.plant-materials. nrcs.gov/pubs/lapmcpg7412.pdf>.

Grimoldi, A.A., P. Insausti, G.G. Roitman, and A. Soriano. 1999. Responses to flooding intensity in Leontodon taraxacoides. New Phytol. 141:119-128.

Hester, M.W. and I.A. Mendelssohn. 1987. Seed production and germination response of four Louisiana populations of Uniola paniculata (Gramineae). Amer. J. Bot. 74:1093-1101.

Hester, M.W. and I.A. Mendelssohn. 1989. Water relations and growth responses of Uniola paniculata (sea oats) to soil moisture and water-table depth. Oecologia 78:289-296.

Houser, C., C. Hobbs, and B. Saari. 2008. Posthurricane airflow and sediment transport over a recovering dune. J. Coast. Res. 24:944-953.

International Seed Testing Association. 2008. International rules for seed testing. ISTA, Bassersdorf, Switzerland.

Laan, P. and C.W.P.M. Blom. 1990. Growth and survival responses of Rumex species to flooded and submerged conditions: The importance of shoot elongation, underwater photosynthesis and reserve carbohydrates. J. Expt. Bot. 41:775-783.

Laan, P., M. Tosserams, C.W.P.M. Blom, and B.W. Veen. 1990. Internal oxygen transport in Rumex species and its significance for respiration under hypoxic conditions. Plant Soil 122:39-46.

Lane, C., S.J. Wright, J. Roncal, and J. Maschinski. 2008. Characterizing environmental gradients and their influence on vegetation zonation in a subtropical coastal sand dune system. J. Coast. Res. 24(S3):213-224.

Lonard, R.I., F.W. Judd, and R. Statler. 2011. Biological flora of coastal dunes and wetlands: Uniola paniculata L. J. Coast. Res. 27:984-993.

Lonard, R.I., F.W. Judd, and R. Stalter. 2012. The biological flora of coastal dunes and wetlands: Salicornia bigelovii J. Torrey. J. Coastal Res. 282:719-725.

Mohammed, A.R. and L. Tarpley. 2011. Effects of high night temperature on crop physiology and productivity: Plant growth regulators provide a management option, p. 153-172. In: S. Casalegno (ed.). Global warming impacts-Case studies on the economy, human health, and on urban and natural environments. InTech DOI: 10.5772/24537.

Morton, R.A., T.L. Miller, and L.J. Moore. 2004. National assessment of shoreline change: Part 1. Historical shoreline changes and associated coastal land loss along the U.S. Gulf of Mexico. U.S. Geological Survey Open-File Report 2004-1043. 18 July 2014. <http://pubs.usgs.gov/of/ 2004/1043/ofr-2004-1043.pdf>.

Saxton, A. 1998. A macro for converting mean separation output to letter groupings in Proc Mixed, p. 1243-1246. In: Proc. 23rd SAS Users Group Intl., SAS Institute, Cary, NC.
Sman, A.J.M.V.D., L.A.C.J. Voesenek, C.W.P.M. Blom, F.J.M. Harren, and J. Reuss. 1991. The role of ethylene in shoot elongation with respect to survival and seed output of flooded Rumex maritimus L. plants. Funct. Ecol. 5:304-313.

Striker, G., P. Insausti, A. Grimoldi, E. Ploschuk, and V. Vasellati. 2005. Physiological and anatomical basis of differential tolerance to soil flooding of Lotus corniculatus L. and Lotus glaber Mill. Plant Soil 276:301-311.

Valk, A.G. 1977. The role of leaves in the uptake of nutrients by Uniola paniculata and Ammophila breviligulata. Chesap. Sci. 18:77-79

VanToai, T.T., S.K. St. Martin, K. Chase, G. Boru, V. Schnipke, A.F. Schmitthenner, and K.G. Lark. 2001. Identification of a QTL associated with tolerance of soybean to soil waterlogging. Crop Sci. 41:1247-1252.

Vartapetian, B.B. and M.B. Jackson. 1997. Plant adaptations to anaerobic stress. Ann. Bot. (Lond.) 79:3-20.

Visser, E.J.W., J.D. Cohen, G.W.M. Barendse, C.W.P.M. Blom, and L.A.C.J. Voesenek. 1996. An ethylene-mediated increase in sensitivity to auxin induces adventitious root formation in flooded Rumex palustris Sm. Plant Physiol. 112:1687-1692.

Voesenek, L.A.C.J., J.H.G.M. Rijnders, A.J.M. Peeters, H.M. van de Steeg, and H. de Kroon. 2004. Plant hormones regulate fast shoot elongation under water from genes to communities. Ecology $85: 16-27$.

Wagner, R.H. 1964. The ecology of Uniola paniculata L. in the dune-strand habitat of North Carolina. Ecol. Monogr. 34:79-96.

Woodhouse, W.W., E.D. Seneca, and A.W. Cooper. 1968. Use of sea oats for dune stabilization in the Southeast. Shore Beach 36:15-21. 